\title{
The Constitutionality of Legislative
}

\section{Supermajority Requirements:}

\author{
A Defense
}

\author{
John O. McGinnis ${ }^{\dagger}$ and Michael B. Rappaport ${ }^{\dagger \dagger}$
}

\section{INTRODUCTION}

On the first day of the 104th Congress, the House of Representatives adopted a rule that requires a three-fifths majority of those voting to pass an increase in income tax rates. ${ }^{1}$ This three-fifths rule had been publicized during the 1994 congressional elections as part of the House Republicans' Contract with America. ${ }^{2}$ In a recent Open Letter to Congressman Gingrich, seventeen well-known law professors assert that the rule is unconstitutional. ${ }^{3}$ They argue that requiring a legislative supermajority to enact bills conflicts with the intent of the Framers. They also contend that the rule conflicts with the Constitution's text, because they believe that the Constitution's specific supermajority requirements, such as the requirement for approval of treaties, indicate that simple majority voting is required for the passage of ordinary legislation. ${ }^{4}$

$\dagger$ Professor of Law, Benjamin N. Cardozo Law School.

it Professor of Law, University of San Diego School of Law. The authors would like to thank Larry Alexander, Akhil Amar, Carl Auerbach, Jay Bybee, David Gray Carlson, Lawrence Cunningham, Neal Devins, John Harrison, Michael Herz, Arthur Jacobson, Gary Lawson, Nelson Lund, Erela Katz Rappaport, Paul Shupack, Stewart Sterk, Eugene Volokh, and Fred Zacharias for their comments and assistance.

1. See RULES OF THE HOUSE OF REPRESENTATIVES, EFFECTIVE FOR ONE HUNDRED FOURTH CONGRESS (Jan. 4, 1995) [hereinafter RULES] (House Rule XXI(5)(c)); see also id. House Rule XXI(5)(d) (barring retroactive tax increases).

2. The rule publicized in the Contract with America was actually broader than the one the House enacted. The publicized proposal would have required a three-fifths vote "to pass a tax increase." See CONTRACT WITH AMERICA 8 (Ed Gillespie \& Bob Schellhas eds., 1994).

3. See An Open Letter to Congressman Gingrich, 104 YALE L.J. 1539 (1995) [hereinafter Open Letter] (signed by Bruce Ackerman and 16 others).

4. A group of members of the House of Representatives challenged the constitutionality of the threefifths rule in federal district court. See Skaggs v. Carle, No. 95-251, 1995 U.S. Dist. LEXIS 13772 (D.D.C. Aug. 23, 1995). The district court dismissed the suit on grounds of "equitable discretion," stating that "federal courts should generally refrain, as a matter of policy, from intruding in the name of the Constitution upon the internal affairs of Congress at the behest of lawmakers who have failed to prevail in the political process." Id. at *5-6. The decision is being appealed. See Benjamin Sheffner, Judge Jettisons Lawsuit on New Tax-Hike Rule, Roll CALL, Sept. 4, 1995, at 3. 
Despite the prominence of its signers, we believe that the Open Letter seriously misconstrues the Constitution. Under the Rules of Proceedings Clause, the House may enact a rule governing its internal operations so long as the rule does not violate another provision of the Constitution. The Open Letter fails to identify a constitutional clause that prohibits the three-fifths rule. The Open Letter's attempt to establish a constitutional requirement of majority rule fails because the only inference that can be drawn from the provisions requiring supermajorities in certain instances is that the Constitution itself does not require a supermajority for the passage of legislation. Thus, the Constitution's silence on the proportion of legislators necessary to pass bills is not the result of inattention to the issue. Rather, it reflects the Framers' intent to permit the houses of the legislature to decide the question. When the Constitution mandates a legislative majority, as it does for quorums, or a supermajority, as it does for treaties, it does so explicitly.

The Open Letter's arguments based on the intent of the Framers fare no better. The Framers' discussions cited in the Open Letter address only the issue of whether the Constitution imposes a supermajority rule rather than whether the Rules of Proceedings Clause authorizes a house to pass a supermajority rule. Far better evidence of the Framers' intent regarding that clause is the unbroken tradition, stretching from the early Republic to the present day, of rules, such as those sustaining the filibuster and the committee system, whose objective has been the same as the three-fifths rule-to frustrate legislative majorities and promote other values. Invalidating the three-fifths rule would also require use of a subjective standard that could create chaos because legislators and citizens would not be sure what rules were valid and thus which enactments were law.

In contrast, the appropriate standard-that standing rules of the legislature are valid so long as the rules are themselves subject to repeal or emendation by majority vote-is easily applied and best comports with the text of the Constitution and our legislative traditions. The Open Letter argues that the three-fifths rule would run afoul of even this standard because the rule cannot be waived or amended by a majority of the House. The Open Letter, however, seriously misunderstands the mechanisms by which the House of Representatives passes legislation: A simple majority of the House can waive or amend the three-fifths rule.

In addition to being wholly constitutional, the three-fifths rule for income tax increases is also good policy. For the last fifty years the Republic has been beset by a difficult problem: Concentrated interest groups can successfully obtain benefits for themselves and place the costs on a diffuse, and therefore legislatively ineffective, popular majority. Rather than being criticized, the rule 
should be celebrated because it is a modest attempt to restore the effective power of popular majorities without taking the more radical step of amending the Constitution.

\section{The CONSTITUTION AUTHORIZES THE THREE-FIFTHS RULE}

The Constitution grants each house the authority to "determine the Rules of its Proceedings." Rules of proceedings are rules that govern the operations of a house of the legislature. ${ }^{6}$ On its face, the three-fifths rule is a rule of proceeding. The rule provides that " $[\mathrm{n}] \mathrm{o}$ bill . . . carrying a Federal income tax rate increase shall be considered as passed . . . unless so determined by a vote of not less than three-fifths of the Members voting."7 The rule governs how the House may pass an increase in income tax rates. The passage of bills and other measures is one of the most important functions that legislatures perform. A legislature must be able to issue rules that determine whether a bill will be deemed to have passed the legislature, including rules on permissible voting methods and the number of votes required. It is difficult to imagine that the Framers would have deprived the houses of the authority to pass rules of this kind. Although legislative rules usually require only a majority to pass a bill, nothing in the Rules of Proceedings Clause prevents the houses from using nonmajority rules. ${ }^{8}$ Thus, just as the text of the Rules of Proceedings Clause authorizes the House to issue a rule providing that bills pass by majority vote, it also authorizes the issuance of a rule providing for a supermajority. A supermajority rule would be illegal only if it conflicted with some other clause of the Constitution or some implicit constitutional principle. ${ }^{9}$ In this part, we show that nothing in the Constitution requires majority voting for all

5. U.S. CONST. art. I, \& S, cl. 2.

6. When the Constitution was enacted, a body of rules already existed governing parliamentary proceedings. See 1 WILliam BlaCKSTONE, COMMENTARIES *159-82; 3 JOSEF REDLICH, THE PROCEDURE OF THE HOUSE OF COMMONS $37-41$ (1908). These rules governed issues such as the powers of committees, permissible amendments, and the scheduling of house business. See 3 JOHN HATSELL, PRECEDENTS OF Proceednas IN THE House of Commons 100 (London, H. Hughes Co., 2d ed. 1785) (amendments inflicting pecuniary penalties); 2 REDLICH, supra, at 203-14 (committees); 3 id. at 37-41 (order of business).

7. RULES, supra note 1 , House Rule XXI(5)(c).

8. Cf. United States v. Ballin, 144 U.S. 1, 5 (1892) ("It is no objection to the validity of a rule that a different one has been prescribed and in force for a length of time.").

9. For instance, the House of Representatives could not use the authority of the Rules of Proceedings Clause to adopt a rule permitting individuals other than members of the House to vote on legislation, because such a rule would violate the provision of Article I, Section 2, Clause 1 that states that "It]he House of Representatives shall be composed of Members . . . ." See Michel v. Anderson, 14 F.3d 623, 630 (D.C. Cir. 1994) (holding that House is precluded "from bestowing the characteristics of membership on someone other than those" chosen as members under procedures specified by Article I of the Constitution). 
legislation and that the Rules of Proceedings Clause does not distinguish between rules that promote debate and those that do not. ${ }^{10}$

\section{A. The Constitution Does Not Mandate Majority Voting for Bills}

Although the Open Letter asserts that the Constitution forbids the House from requiring a supermajority to pass a bill, the Constitution simply does not contain such a prohibition. The Open Letter tries to derive the prohibition on the basis of arguments drawn from the text of the Constitution, the intent of the Framers, and Supreme Court precedent, but none of these claims are persuasive.

\section{Text}

The Constitution addresses the power of each house to pass bills principally in the Presentment Clause, which provides that "[e]very Bill which shall have passed the House of Representatives and the Senate, shall, before it become a Law, be presented to the President of the United States."11 Additionally, the Orders Presentment Clause states that "[e]very Order, Resolution, or Vote to which the Concurrence of the Senate and House of Representatives may be necessary ... shall be presented to the President."12

Neither clause specifies the proportion of a chamber necessary to pass a bill. Rather, the clauses simply refer to a bill's passage by a house or an order's receipt of the concurrence of a house. The Constitution's failure to specify a proportion necessary to pass a bill, combined with the delegation of authority to each house under the Rules of Proceedings Clause, suggests that the Constitution permits each house to decide how many members are necessary to pass a bill.

The Constitution's silence on the number necessary to pass a bill stands in stark contrast to other provisions that specify the requisite number to undertake particular actions. Most significantly, the Quorum Clause states that

10. In addition to the three-fifths rule, the House also passed a rule prohibiting a retroactive income tax rate increase. See RULES, supra note 1, House Rule XXI(5)(d). This rule is also a rule of proceeding. The rule governs what measures may be considered and voted upon by the House. Rules governing the agenda of a chamber are common, including the rules that prevent the House in the ordinary course from considering bills that have not been reported out of committee. Because the retroactivity rule is a rule of proceeding, the Constitution grants the House authority to pass it as well. As with the three-fifths rule, the rule will be constitutional unless it violates another constitutional provision.

11. U.S. CONST. art. I, \& 7, cl. 2.

12. Id. art. I, $\S 7$, cl. 3 . Congress's power to pass bills is also implicated in id. art. I, $\$ 1$, which provides that "[a]ll legislative Powers herein granted shall be vested in a Congress of the United States, which shall consist of a Senate and House of Representatives." 
"a Majority of each [house] shall constitute a Quorum to do Business."13 The Quorum Clause shows that, when the Framers thought it important, they could expressly establish a majoritarian requirement in the Constitution. The Clause rebuts the argument that the Constitution silently incorporates majoritarian rules of parliamentary procedure. Thus, the Quorum Clause strongly supports the conclusion that, when the Constitution does not specify a proportion, each chamber may determine the number of members necessary to take action. ${ }^{14}$

Other provisions of the Constitution similarly undermine the claim that there is an implicit requirement of majority voting. Their language reveals that the Framers did not leave constitutional voting requirements to speculation, but made them explicit where there would otherwise be doubt about their content. For instance, the Constitution is clear when it requires less than a majority, as when it states that "one fifth of those Present" in either house may insist that there be a roll call vote recorded in the journal. ${ }^{15}$ Likewise, the Constitution is explicit in the many places where it requires a supermajority. ${ }^{16}$ Indeed, the Presentment Clause itself states that two-thirds of each house are necessary to override the President's veto. ${ }^{17}$

Oddly enough, the Open Letter relies principally on these supermajority requirements as the textual basis for its conclusion that the three-fifths rule is

13. Id. art. I, § 5, cl. I.

14. It might be argued that it would be incongruous for the Framers to have required a majority for a quorum, but not for the passage of legislation. But there is nothing strange about requiring a majority for a quorum but permitting a chamber to require a supermajority to pass legislation. The Framers had reason to treat the two situations differently, because preventing a minority from defeating a quorum may be understood as far more important than preventing a majority from impeding legislation. A minority that attempts to block legislation must confront the many political pressures that induce legislatures to behave reasonably, such as debate, deliberation, and publicity. By contrast, a minority that defeats a quorum will be much less vulnerable to these pressures because the failure to establish the quorum will prevent the operation of the legislature and simultaneously frustrate the political dynamics that constrain the legislators' behavior. Indeed, the majority needed for a quorum is clearly not the same as the majority needed to pass legislation: The majority needed for a quorum is a majority of the entire house, but the number ordinarily required to pass legislation is a majority of the quorum. That no one argues that a majority of the entire house is needed to pass legislation suggests a recognition that the rule for a quorum and the rule for passing legislation have different functions. It is thus perfectly logical that the rule for a quorum be constitutionally mandated, but the rule for passage of legislation be left to the discretion of the legislative majority.

15. U.S. CONST. art. I, $\S 5$, cl. 3.

16. See id. art. I, \& 3, cl. 6 (two-thirds Senate vote needed for conviction in impeachment); id. art. I, $\S 5, \mathrm{cl} .2$ (two-thirds vote of applicable house needed to expel member); id. art. I, $\S 7, \mathrm{cl}$. 2 (two-thirds vote of both houses needed to overrule presidential veto); id. art. II, $\S 2, \mathrm{cl} .2$ (two-thirds Senate vote needed to ratify treaty); id. art. V (two-thirds vote of both houses needed to propose constitutional amendments); id. amend. XIV, \& 3 (two-thirds vote of both houses needed to remove disability for office of any prior federal or state officer who engaged in insurrection against U.S. government or gave aid to enemies); id. amend. XXV, $\S 4$ (two-thirds vote of both houses needed for determination that President is unable to discharge powers and duties of office).

17. The Constitution's requirement that a majority be able to repeal a rule of proceeding, which we discuss in Section II.B, was not made explicit because the Framers did not appear to consider it an open question. The historical and structural evidence supporting the requirement was powerful. 
unconstitutional. ${ }^{18}$ According to the Open Letter, it is telling that the Constitution specifically imposes supermajority requirements in seven places, but not as to ordinary bills. Thus, the argument goes, because the Constitution "never places any special obstacles in the way of the enactment of ordinary legislation," the House may not do so. ${ }^{19}$

This argument is wholly misdirected. That the Constitution elsewhere expressly imposes supermajority requirements would be a strong argument against the claim, if anyone made it, that the Presentment Clause implicitly requires a supermajority to pass a bill. The existence of seven supermajority requirements in the Constitution, however, provides no support for the conclusion that the Constitution forbids the houses from passing other supermajority rules. There is nothing strange about the Framers refusing to impose a supermajority requirement but permitting the legislature to do so. ${ }^{20}$ The problem with the Open Letter's argument is that it assumes a prohibition on legislative supermajority rules simply because they are not constitutionally prescribed.

The weakness in the structure of the Open Letter's position may be made even more obvious by a review of analogous arguments. The Constitution requires each house to keep a journal, ${ }^{21}$ but no one would argue that this provision disables each house from directing under its Rules of Proceedings Clause that other kinds of records of its proceedings also be printed. The Constitution requires the President to report on the "State of the Union,"22 but no one would argue that he is constitutionally disabled from sending messages to Congress on other subjects.

Surprisingly, the Open Letter argument with the most surface appeal is in a footnote. The Open Letter suggests that the constitutional provision giving the Vice President a vote only when the Senate is equally divided indicates that the Framers required the houses to use majority voting. ${ }^{23}$ The Vice President Voting Clause, however, does not begin to support a majority rule requirement. The clause simply reflects the Framers' reasonable assumption that the houses would often choose to use majority rule and that majority rule would be the default rule applied when no other procedure was adopted. ${ }^{24}$ The Constitution itself shows that the Framers could not possibly have thought that the Vice President would have the potential to cast a vote on every roll

18. See Open Letter, supra note 3, at 1541.

19. Id.

20. Indeed, this is the normal situation as to the passage of legislation generally. The Constitution does not prescribe legislation, but instead permits Congress to enact it as Congress deems desirable.

21. See U.S. CONST. art. I, \& 5, cl. 3.

22. See id. art II, § 3 .

23. See Open Letter, supra note 3, at 1541 n.9.

24. For further discussion of the default rule, see infra note 50 and accompanying text. 
call because it requires a two-thirds majority rather than a simple majority for the Senate to pass a treaty, ${ }^{25}$ propose a constitutional amendment, ${ }^{26}$ expel a member, ${ }^{27}$ or impeach an officer of the United States. ${ }^{28}$ Thus, the Vice President has no power to cast a vote in a wide variety of important situations, demonstrating that the Framers could not have thought that the Vice President Voting Clause had to be given effect whenever the Senate votes.

Moreover, as we argue below, the rules of each house are subject to repeal by majority vote. ${ }^{29}$ Thus, even if the Senate exercised its authority under the Rules of Proceedings Clause to require all legislation to pass by supermajority vote, votes on the repeal of such rules would always provide opportunities for the Vice President to cast a vote. Thus, under our construction of the Rules of Proceeding Clause, the Vice President Voting Clause would never become superfluous.

The Open Letter also finds problematic that the three-fifths supermajority required for income tax increases is different from the various two-thirds majorities required by the Constitution. ${ }^{30}$ The Open Letter worries about the "proliferation of supermajority" rules with incongruous requirements of $55 \%$ or $73 \%$. But such quibbles do not supply a constitutional argument. In delegating to the houses the authority to pass voting rules, the Constitution permits them to choose unusual or odd proportions. Moreover, for a variety of reasons, the houses are likely to choose simple proportions. ${ }^{31}$ In fact, the houses have often in the past chosen a simple three-fifths requirement, ${ }^{32}$ presumably because they believe a two-thirds requirements is too strict.

\section{Framers' Intent}

The Open Letter supplements its textual argument with an argument concerning the intent of the Framers. The Open Letter argues that the Framers

25. See U.S. ConST. art. II, § 2, cl. 2.

26. See id. art. V.

27. See id. art. I, § 5, cl. 2.

28. See id. art. I, § 3, cl. 6 .

29. See infra notes $97-107$ and accompanying text.

30. See Open Letter, supra note 3 , at 1541 . Considered by itself, this is a strange argument to make. Do the authors of the Open Letter really believe that the three-fifths rule would be on surer constitutional footing if it required a two-thirds vote?

31. One would expect a chamber to choose round numbers to avoid suspicion that a rule with odd proportions was selected by counting heads in advance. Roundness thus provides a greater assurance of neutrality. A house might also choose round numbers to avoid the ridicule that odd proportions might provoke.

32. See, e.g., United StaTes Senate, SEnate ManUal (1993) [hereinafter Senate ManUal] (Senate Rule XXII(2)) (requiring three-fifths for cloture); Omnibus Budget Reconciliation Act of 1990, Pub. L. No. 101-508, § 13208, 104 Stat. 1388, 1619 (1990) (requiring three-fifths to waive certain budget rules). 
wanted to prohibit supermajority voting rules. ${ }^{33}$ The Open Letter relies on a passage from The Federalist No. 58 in which James Madison defends the Philadelphia Convention's decision not to constitutionally require a supermajority for a quorum or for particular types of legislation. Although Madison did not entirely agree with the Convention's decision, ${ }^{34}$ he argues in The Federalist that a supermajority requirement would reverse the "fundamental principle of free government." $\mathrm{He}$ also states that a constitutionally required supermajority would permit a minority to take advantage of the public. ${ }^{36}$

At first glance, Madison's remarks appear to create a puzzle. If the Framers really intended to prohibit supermajority voting rules, why does the text show so little evidence of the prohibition? The puzzle soon vanishes as further inspection reveals that Madison was addressing an entirely different question than that raised by the Open Letter. Madison was explaining why the Framers did not establish a constitutional supermajority requirement. ${ }^{37}$ The present issue concerns the validity of a legislative supermajority requirement.

Legislative supermajority requirements also do not raise the problems that Madison identified with constitutional supermajority rules. ${ }^{38}$ Permitting houses to pass supermajority requirements would not allow a minority to take advantage of the public. ${ }^{39}$ A supermajority rule would only be passed if a

33. Open Letter, supra note 3 , at 1540.

34. In the Philadelphia Convention, Madison argued that a quorum of the Senate should require a twothirds supermajority, but his view did not prevail. ARTHUR T. PRESCOTT, DRAFTiNg THE FEDERAL CONSTITUTION 426 (1941). We do not believe that the argument expressed in The Federalist should be discounted simply because Madison may not have agreed with it. After all, he defended the Constitution on this ground, and the Convention disagreed with his original position. We do believe, however, that Madison's belief significantly undermines the Open Letter's attempt to rely on his authority. We also believe that Madison's original view shows, as do the other supermajority requirements in the Constitution, that there was no consensus that supermajority requirements were generally inappropriate.

35. THE FEDERALIST No. 58, at 361 (James Madison) (Clinton Rossiter ed., 1961).

36. Such a requirement might enable a minority to use its voting power to screen itself from equitable obligations or to extort special benefits during an emergency.

37. Similarly, Alexander Hamilton's discussion in The Federalist No. 22 also addresses the question of the extent to which the Constitution should impose requirements that restrain majorities. See THE FEDERALIST No. 22, at 147-48 (Alexander Hamilton) (Clinton Rossiter ed., 1961).

38. It follows from the logic of our position that the Rules of Proceedings Clause also authorizes a house to pass a rule allowing for the passage of bills by less than a majority vote. Minority voting rules, however, sometimes create practical difficulties, because one minority could repeal provisions that another minority had passed. A useless cycle of passage and repeal could result. More narrowly drawn minority voting rules can avoid these problems and have been used successfully by various government institutions. For example, the Constitution permits a minority in a house to require a roll call vote, and the Supreme Court permits four Justices to grant certiorari from a lower court decision. See Lawrence C. Marshall, "Let Congress Do It": The Case for an Absolute Rule of Statutory Stare Decisis, 88 MICH. L. REV. 177, 235 n.279 (1989).

39. Even Madison's brief remarks criticizing constitutional supermajority requirements contain evidence that he might have approved of certain legislative supermajority rules. Madison acknowledged that there are advantages in supermajority requirements-they protect vulnerable groups and impede bad legislation-but he believed that they were outweighed by disadvantages. See THE FEDERALIST No. 58, supra note 35 , at 361 . But Madison may simply have believed that constitutional supermajority 
majority believed it was appropriate, and it could be repealed if the majority believed that a minority was using its powers improperly. ${ }^{40}$

That the Framers opposed many constitutional supermajority requirements does not suggest that they also opposed legislative supermajority requirements, because the policies underlying the two types of requirements differ. ${ }^{41}$ While constitutional supermajority requirements conflict with majority rule, legislative supermajority requirements do not. A legislative supermajority rule simply involves a majority imposing a supermajority requirement upon itself until the majority decides to eliminate it. $^{42}$ Permitting the legislature to adopt a supermajority requirement respects majority rule in more important ways than does a prohibition on legislative supermajority rules. Allowing the legislature to adopt supermajority requirements permits the majority to make crucial decisions-to adopt supermajority rules and possibly to eliminate them-that a prohibition would deny. ${ }^{43}$

requirements were too broad and undiscriminating. He may have believed that legislatures could determine when supermajority rules would be beneficial and therefore might have approved of the particular supermajority rules that legislatures might pass. Indeed, it is quite possible that Madison might have approved of the three-fifths rule, given the large increases in taxes and frequent changes in tax rates in recent decades.

40. If the rules governing how a bill or rule may be passed are rules of proceedings that each house has the power to enact, under what rules does a house act before any rules have been enacted? For example, because the rules of the 103d Congress are deemed to have terminated with that Congress, under what rules did the House of Representatives of the 104th Congress act when it passed by a majority vote its new rules, including the three-fifths rule? The House of Representatives has historically followed the view that, prior to the passage of the House rules, the House is governed by legislative common law. 1 DESCHLER'S PRECEDENTS OF THE UNITED STATES HOUSE OF REPRESENTATIVES 55, 308-09 (1976). There is a strong argument for recognizing this legislative common law. The common law has its strongest appeal in areas where there are traditional rules and the legislature is not able to be the exclusive promulgator of the rules. These conditions certainly hold for legislative rules during the period before the legislature has had the opportunity to make these rules itself. In addition, the British Parliament's use of legislative common law, 2 REDLICH, supra note 6, at 3-9, suggests that the Framers considered it a valid means of governing the legislature. One would expect that the common law legislative rules would incorporate majority voting, because that is traditionally the most common voting rule. The common law, however, would not prevent the House from enacting a supermajority rule.

41. As Madison's discussion indicates, the Philadelphia Convention considered and rejected certain constitutional supermajority requirements (although it did, of course, adopt several others). See, e.g., 2 MAX FARRAND, THE RECORDS OF THE FEDERAL CONVENTION OF 1787, at 449-51 (1911) (discussing proposed constitutional supermajority requirement to pass regulations of commerce); id. at 631 (discussing proposed constitutional supermajority requirement to pass navigation acts). Our analysis of Madison's statement also applies here: The Framers' rejection of certain constitutional supermajority requirements does not indicate that they also prohibited legislative supermajority requirements.

42. Contrary to the assertions of the Open Letter, a majority can eliminate the supermajority requirement. See infra Section II.A.

43. Because it is easy to confuse constitutional and legislative supermajority requirements, care must be taken when interpreting statements about this subject. For example, some opponents of ratification criticized the Constitution because it did not require supermajorities in certain instances but instead permitted Congress to enact laws based on majority rule. See GEORGE MASON, OBJECTIONS TO THE CONSTITUTION OF GOVERNMENT FORMED BY THE CONVENTION (1787), reprinted in 2 HERBERT J. STORING, THE COMPLETE ANTI-FEDERALIST 9, 12 (1981) (criticizing fact that Constitution permits "only a Majority" to pass certain laws); A Letter of His Excellency Edmund Randolph Esquire, on the Federal Constitution (Oct. 10,1787), reprinted in 2 STORING, supra, at 86, 97 (criticizing "submission of commerce 


\section{Judicial Precedent}

The Open Letter also argues that the three-fifths rule conflicts with the Chadha decision. ${ }^{44}$ It contends that requiring a legislative supermajority is inconsistent with Chadha's holding that Congress can change the constitutional requirements for the passage of legislation only by constitutional amendment. If the Constitution contained a majority-voting requirement for legislation, Chadha would, of course, support the conclusion that Congress could not depart from the requirement. But the question here is whether the Constitution contains such a requirement, and Chadha provides no guidance on this point. ${ }^{45}$

The Open Letter also claims support from United States v. Ballin. ${ }^{46}$ In Ballin, the Supreme Court reviewed a House rule that counted toward a quorum members who were present in the hall but did not vote. The Court held that the rule was a rule of proceeding that reasonably determined whether a quorum existed and therefore was consticutional. The Open Letter quotes language from the decision that, at first glance, might be thought to suggest that the Supreme Court implied that supermajority rules are unconstitutional: ${ }^{47}$

The other branch of the question is, whether, a quorum being present, the bill received a sufficient number of votes; and here the general rule of all parliamentary bodies is that, when a quorum is present, the act of a majority of the quorum is the act of the body. This has been the rule for all time, except so far as in any given case the terms of the organic act under which the body is assembled have prescribed

to a mere majority in the legislature"). These statements, however, do not suggest that the Constitution prohibits the legislature from passing supermajority requirements. Instead, the statements merely indicate that these opponents understood that the Constitution permits a majority to pass legislation in this area and assumed that Congress would employ the usual majority voting rule.

44. INS v. Chadha, 462 U.S. 919 (1983).

45. Chadha also contains some language that might be misinterpreted as suggesting that the Constitution mandates a majority vote to pass legislation. One example arises in a section of the opinion where the Court explains that, when the Constitution does not mandate bicameralism and presentment, it sometimes imposes a supermajority requirement. The Court gives as an example that "Art. II, $\$ 2$ requires that two-thirds of the Senators present concur in the Senate's consent to a treaty, rather than the simple majority required for passage of legislation." Id. at $956 \mathrm{n} .21$. This language should not be understood to suggest that the Constitution requires that legislation be passed by majority vote; rather, it should be interpreted as a shorthand reference to the fact that the Constitution does not require a supermajority to pass bills and that the usual legislative rule permits bills to be passed by a majority. Under our interpretation, the Court's argument that a supermajority would be needed instead of bicameralism and presentment makes perfect sense. Any other interpretation would be extraordinary because it would view the Court as taking a controversial position in a footnote on an issue that is not raised in the case and offering no analysis in support of its position. For another example of language that might similarly be misinterpreted to require a majority vote, see id. at 958 .

46. 144 U.S. 1 (1891).

47. Open Letter, supra note 3 , at 1543. 
specific limitations. ... No such limitation is found in the Federal Constitution, and therefore the general law of such bodies obtains. ${ }^{48}$

Despite first appearances, however, the Court's statement is not addressing the issue of whether the legislature can require a supermajority to take action. That issue is neither discussed in the opinion nor raised by the facts of the case.

Interpreting the Court as addressing whether the legislature can pass supermajority rules is mistaken for additional reasons. It would mean that the Court made an erroneous historical claim because, as we show below, it was understood in the nineteenth century that legislatures could enact supermajority rules. $^{49}$ Moreover, that interpretation would suggest that all legislative supermajority rules are unconstitutional, even though the Open Letter acknowledges that supermajority rules addressed to procedural issues are neither unconstitutional nor unusual.

The better interpretation is that the Ballin Court is discussing the rule that applies when neither the Constitution nor the legislature imposes a specific rule, such as a supermajority rule. Under this interpretation, the Court correctly states that the universal default rule is that a majority of the quorum may take action. The Court is also addressing an issue that the case raises, because the House had not displaced the default rule.$^{50}$ Nothing in the Court's discussion, however, indicates that the Rules of Proceedings Clause found in the Constitution - "the organic act under which [Congress] is assembled"51_fails to authorize the House to pass a supermajority rule if it chooses to supersede the default rule.

While the Open Letter's argument is not supported by Supreme Court precedent, our position on supermajority rules comports with venerable authority. ${ }^{52}$ A century and a half ago, Luther Cushing, who was clerk of the Massachusetts House of Representatives for twelve years, published a thousand-page treatise on legislative procedure that "was received with universal approval.,53 Cushing recognized that legislative majorities sometimes chose to depart from simple-majority voting rules, but argued that

48. Ballin, 144 U.S. at 6.

49. See infra notes $52-54$ and accompanying text.

50. Consistent with this interpretation, the Ballin Court labels majority rule "the general rule," Ballin, 144 U.S. at 6 (emphasis added), implying that the norm is open to modification.

51. Id.

52. Our conclusion also accords with the opinion of the executive branch. See Constitutionality of Proposed Budget Process Reform Legislation, 11 Op. Off. Legal Counsel 57 (1987) [hereinafter OLC Opinion] (providing that legislation granting to Congressional Budget Office the ability to trigger supermajority vote on budget items was within Congress's authority under Rules of Proceedings Clause). (At the time this opinion was rendered, the authors were employed by the Office of Legal Counsel, but they had no part in researching or writing this opinion.)

53. 2 Dictionary OF AMERICAN BIOGRAPHY 632 (Allen Johnson \& Dumas Malone eds., 1930). 
this deviation was consistent with majoritarian principles. He concluded that a nonmajoritarian rule may be

prescribed, by some paramount authority, or ... agreed upon beforehand and established by the assembly itself, by which a smaller number is permitted, or a larger number is required, to do some particular act. But even in these cases, it is the will of the majority that governs; because it is by a major [sic] vote, in the first instance, that the rule itself is established. ${ }^{54}$

\section{B. The Rules of Proceedings Clause Is Not Limited to Rules that Promote Debate}

In addition to arguing that the Constitution directly prohibits rules that require supermajority votes to pass bills, the Open Letter also argues that the three-fifths rule is not even a rule of proceeding within the authority of each house to pass. The Open Letter contends that rules of proceedings are confined to rules that contribute to "informed discussion" and are procedural rather than substantive. ${ }^{55}$ This interpretation is mistaken.

\section{Text}

The text of the Rules of Proceedings Clause does not suggest that it should be limited to rules that are procedural or that advance deliberation. The distinction to be drawn is not between procedure and substance, but between acts that govern the operations of a house of the legislature and those that alter the rights and duties of citizens outside the legislative branch. The former are within the ambit of the Clause, and the latter are exercises of legislative power that fall outside the Clause. Permitting each house to govern its operations accords with the text and purposes of the Rules of Proceedings Clause, prior judicial precedent, and the rules of proceedings that Congress has adopted for two hundred years. In contrast, the Open Letter's interpretation of the Clause conflicts with Supreme Court precedent and would cast doubt on our most venerable legislative practices, including those patterned after practices of the British Parliament.

54. LUTHER S. CUSHING, ElEMENTS OF THE LAW AND PRACTICE OF LEGISLATIVE ASSEMBLIES IN THE UNITED STATES OF AMERICA 168 (Boston, Little, Brown and Co. 1856). As we discuss below, the threefifths rule is clearly a rule of the majority in Cushing's sense because a House majority adopted it and may repeal it.

55. See Open Letter, supra note 3, at 1541-43. 
The Rules of Proceedings Clause grants to each house authority over its own proceedings-that is, its operations or business. ${ }^{56}$ This interpretation conforms to the ordinary meaning of "proceedings." It also serves the evident purpose of the Clause in that it gives each house authority to run its own business. In the absence of a grant of authority to each house, Congress would have to rely on its legislative authority under the Necessary and Proper Clause to pass rules of proceedings. ${ }^{58}$ But this would have the troubling consequence of requiring each house to submit its rules to the other house and the President for approval. If the Clause were limited to procedural aspects, this would unduly limit each house's authority to regulate its own affairs. ${ }^{59}$ This interpretation is in keeping with general separation of powers principles by which the Constitution gives each governmental institution sufficient autonomy to act as a counterweight to others.

\section{Precedent}

Our interpretation is also supported by Chadha, the case upon which the Open Letter itself relies. In Chadha, the Court expressly contrasts legislative power, described as the power "of altering the legal rights [and] duties ... outside the Legislative Branch," with Congress's rulemaking authority, interpreted as the power "to bind itself." ${ }^{60}$ Permitting Congress wide latitude with respect to rules relating to its proceedings is also consistent with the broad interpretation of Congress's authority under the Rules of Proceedings Clause in the Supreme Court's most extensive discussion of the subject. In United States v. Ballin, the Court states:

The Constitution empowers each house to determine its rules of proceedings. It may not by its rules ignore constitutional restraints or

56. See U.S. CONST. art. I, $\S 5, \mathrm{cl} .2$. The "business" of the House is precisely that referred to in the Quorum Clause's direction that "a Majority of each [house] shall constitute a Quorum to do Business." Id. art. I, § 5, cl. 1 (emphasis added).

57. The proceedings of an organization or institution are not limited to procedures, but include the business or operations of that organization. Even "legal proceedings" or "proceedings before a court" are not limited to matters of procedure, but extend to both procedural and substantive aspects of a case.

58. See U.S. CoNST. art. I, \& 8, cl. 18.

59. It might be argued that the term "proceedings" suggests "procedure." But if the Framers intended to narrow the rule in this way, they could have provided for "rules of procedure." The term "proceedings" is broader than the Open Letter's narrow use of "procedure." Of course, one might interpret "procedure" broadly to include all procedures or actions of a house, but then the three-fifths rule would be procedural in this sense.

60. INS v. Chadha, 462 U.S. 919, 952, 955-56 n.21 (1983) (emphasis added). Of course, when the Court stated that the Rules of Proceedings Clause gave Congress the power to "bind itself," it meant simply that the rules were binding on members of Congress as opposed to individuals or institutions outside Congress. There is no suggestion that the Court meant to disturb the longstanding view that one Congress could not bind another. 
violate fundamental rights, and there should be a reasonable relation between the mode or method of the proceeding established by the rule and the result which is sought to be attained. But within these limitations all matters of method are open to the determination of the house, and it is no impeachment of the rule to say that some other way would be better, more accurate or even more just. ${ }^{61}$

The three-fifths rule is a method of proceeding in that it regulates the operations of the House, and a reasonable relation exists between the rule and the need to determine whether an increase in tax rates passed the House. Thus, the reasoning of Ballin supports the constitutionality of the three-fifths rule. ${ }^{62}$

\section{Historical Practice}

The history of the rules of proceedings from the First Congress to the present day also confirms that Congress has the power to make rules that have substantive effects, so long as they also regulate the operations of a chamber. ${ }^{63}$ Indeed, many of the most significant congressional rules frustrate the enactment of majority-supported legislation in order to advance other values. For instance, the rules of the Senate have allowed for filibusters since the early republic. In fact, the first filibuster was attempted in the First Congress. ${ }^{64}$ Indeed, until 1917, the Senate did not have a cloture rule at all; the ability of members to hold up majoritarian legislation was limited only by their endurance. ${ }^{65}$ Even the House of Representatives did not use effective mechanisms to limit debate until Speaker Reed's reforms of the late-nineteenth century. ${ }^{66}$ While the Open Letter declines to endorse the rules permitting

61. United States v. Ballin, 144 U.S. 1, 5 (1891).

62. The three-fifths rule, of course, applies to a particular subject-increases in the rate of taxation-and not to all legislation. However, nothing in the Rules of Proceedings Clause or judicial precedent suggests that Congress is disabled from passing subject-specific rules of proceeding. A requirement that every rule of proceeding apply to all legislation would unaccountably prevent Congress from taking into account relevant differences among legislative subject matters. (For a discussion of the public policy reasons supporting the three-fifths rule, see infra notes 118-28 and accompanying text.) Surely, the House would not be acting unconstitutionally if it abolished a committee with jurisdiction over a particular subject matter and initiated legislation on that subject through the entire House. Yet such action would also create subject-specific rules of proceeding.

63. It might seem odd that the Open Letter argues for this doubtful distinction between procedure and substance because the distinction appears unnecessary to its argument. After all, even if the three-fifths rule is a rule of proceeding, it would still be unconstitutional if the Presentment Clause required majority votes. It would appear that the Open Letter needs this distinction to buttress its interpretation of the Presentment Clause.

64. See Frankin L. Burdette, Filibustering in the Senate 14 (1940).

65. Id. at $43-80$.

66. ROBERT LUCE, LEGISLATIVE PROCEDURE 283-88 (1922). 
filibusters, ${ }^{67}$ the continuous use of filibusters since the early Republic provides compelling support for their constitutionality. ${ }^{68}$

No plausible constitutional distinction exists between the rules that have permitted filibusters and the three-fifths rule; if the former is within the historical meaning of the Rules of Proceedings Clause, so is the latter. The filibuster and the three-fifths rule both have the procedural effect of sometimes encouraging deliberation and the substantive effect of giving more power to a minority of legislators. The three-fifths rule, like any supermajority rule, may often promote informed discussion; since a legislator's vote in favor of a tax bill becomes more valuable, individuals may invest more time in persuading the legislator of the bill's merits. ${ }^{69}$ Similarly, permitting unlimited debate leads simultaneously to more deliberation and to greater power for legislative minorities vis-à-vis legislative majorities. ${ }^{70}$ Indeed, whenever the merits of the rules relating to filibusters have been discussed, the central issue in the debate over their wisdom has always been substantive: How much influence should a legislative minority have over the content of legislation? ${ }^{71}$ The exercise of the filibuster is further proof of its substantive nature. Surely, the authors of the Open Letter do not believe that those Southern legislators who filibustered civil rights legislation by, among other things, reading the telephone book were merely promoting deliberation rather than exercising a minority veto.

Like the filibuster, the congressional committee system is an institutional mechanism maintained through legislative rules that temper the power of a chamber's numerical majority. Legislative committees are even more venerable than the filibuster. They were used in the English Parliament from the fourteenth century and thus were part of parliamentary practice well known to

67. See Open Letter, supra note 3, at 1543.

68. See The Pocket Veto Case, 279 U.S. 655, 689 (1929) (noting that "[l]ong-settled and established practice is a consideration of great weight in a proper interpretation" of provisions of Constitution); see also Marsh v. Chambers, 463 U.S. 783 (1983) (upholding practice of legislative prayers that began in First Congress and spanned two hundred years); Walz v. Tax Comm'n, 397 U.S. 664, 678 (1970) (noting that "an unbroken practice . . . is not something to be lightly cast aside" by constitutional challenge).

69. For instance, the unanimity rule for juries has often been defended on the grounds that it leads to more deliberation than a rule permitting a decision by majority or even supermajority. See Saul M. Kassin, The American Jury: Handicapped in the Pursuit of Justice, 51 OHIO ST. L.J. 687, 708-09 (1990) (reviewing multiple studies suggesting that juries making decisions under unanimity rule have longer and better deliberations than juries making decisions under majority rule).

70. The very etymology of "filibuster" shows that the action was originally understood as a barrier to majority rule rather than a perfection of the deliberative process. The word comes from the Spanish "filibusteros," who were West Indian pirates using small vessels called "filibotes" to conduct raids on larger ships. LUCE, supra note 66, at 283. The word "filibuster" is thus cognate with "freebooter," both derived from the Dutch word "vrijbuiter," meaning pirate. THE AMERICAN HERITAGE COLLEGE DICTIONARY 509, 542 (3d ed. 1993).

71. LUCE, supra note 66 , at 297-98. For the most recent reiteration of this point, observe Senator Joseph Lieberman's suggestion that the rules permitting filibusters be repealed because filibusters are inconsistent with majority rule. See Harkin, Lieberman to Fight Use of Senate Filibuster, Gannett News Service, Nov. 22, 1994, available in LEXIS, News Library, GNS File. 
the Framers. ${ }^{72}$ The House of Representatives of the early Republic established both select and standing committees with important powers. ${ }^{73}$ Committees have loomed large in our legislative system ever since. As Woodrow Wilson observed more than a century ago, "Congress in its committee-rooms is Congress at work."74

Legislative rules in both the House and Senate allow committees to act as gatekeepers over legislative initiatives within their jurisdictions, a power which provides them with disproportionate influence over the final content of legislation. ${ }^{75}$ Even if the members of committees were randomly chosen, some committees would be unrepresentative of the preferences of the entire body, and the power afforded these committees would increase the chance that, on some issues, the majority will of the legislative body would be thwarted. Moreover, substantial evidence exists that the preferences of committee members are likely to differ from those of the average member of Congress on issues within the committee's jurisdiction, because members choose committees that are the most useful for aiding their constituents and most conducive for promoting their own reelection. ${ }^{76}$ In addition, on key House committees, such as the Ways and Means and the Rules Committees, the majority party gives itself a more favorable partisan ratio than it enjoys in the entire chamber. ${ }^{77}$ This imbalance also potentially skews the kind of legislation that is enacted. Finally, committee chairmen have substantial power over what legislation is considered in committee, thus providing further nonmajoritarian influence over legislation. ${ }^{78}$

72. For a discussion of the history of committees in the English Parliament, see 2 REDLICH, supra note 6, at 203-07 (detailing history of committees from 1340 through 1700s). Some of these committees had substantial powers. See 2 id. at 206-07.

73. The first standing committee was created in 1789, and, by 1822 , the House had 19 such committees. Malcolm E. Jewell \& Samuel C. Patterson, The Legislative Process in the UnIted STATES 143 (4th ed. 1986). Early Congresses also created select committees to consider particular legislation; over 350 were created in the Third Congress alone. CONGRESSIONAL QUARTERLY, ORIGINS AND DEVELOPMENT OF CONGRESS 99 (2d ed. 1982).

74. WOODROW WILSON, CONGRESSIONAL GOVERNMENT: A STUDY IN AMERICAN POLITICS 79 (Legal Classics Library 1993) (1885).

75. See Kenneth A. Shepsle \& Barry R. Weingast, The Institutional Foundations of Committee Power, 81 AM. POL. SCI. REV. 85, 97-100 (1987) (suggesting that committee members gain their substantial influence over legislation not only through their ability to initiate legislation, but also from their power to dominate conference committees and hence exercise substantial control over final legislative product).

76. Thus, for instance, members from agricultural districts and states may have disproportionate representation on the agricultural committee. See KENNETH A. SHEPSLE, THE GIANT JigSAW PUZZLE: DEMOCRATIC COMMITTEE ASSIGNMENTS IN THE MODERN HOUSE 259 (1978) (suggesting members of committees are unrepresentative of preferences of entire House on issues before committee).

77. See Charles Tiefer, Congressional PRActice and Procedure 90 (1989).

78. See C. LAWRENCE EVANS, LEADERSHIP IN COMMTTEE 45 (1991) (suggesting that control of committee chairpersons over committee agendas represents most significant formal prerogative of leadership). Even apart from the committee system, in the House of Representatives, the Speaker has the substantial power to recognize or decline to recognize motions, which is yet another potentially antimajoritarian power. TIEFER, supra note 77, at 229-32. 
Thus, like the three-fifths rule, the committee system both promotes deliberation and impedes majoritarian legislative control. For instance, the committee system aids concentrated interest groups, since they are likely to be better represented on committees of importance to them than in the House as a whole. The system also advances the institutional interests of the majority party rather than a majority of legislators, particularly in the House of Representatives. In fact, legislation supported by a majority of the House is regularly bottled up in committee when such an obstruction preserves the cohesion of the majority party. Most notoriously, for instance, civil rights legislation was long delayed by senior Democratic members of the Rules Committee even though the legislation commanded majority support in the House. ${ }^{79}$ Many of the items in the recent Contract with America had been prevented from reaching the floor in past Congresses by the Democratic leadership working through the committee system, although those issues commanded majority support of the entire body even before the last election. ${ }^{80}$ We are not aware that any of the signers of the Open Letter have protested the frustration of majority will in Congresses of the last decade. ${ }^{81}$

\section{Jurisprudential Considerations}

The foregoing discussion demonstrates that besides its lack of historical support, the kind of standard that the Open Letter seeks to require of rules that frustrate majoritarian control-for instance, that such rules contribute to deliberative democracy-is hopelessly indeterminate and subjective. ${ }^{82}$ The Open Letter believes that the courts should employ such a standard to invalidate the three-fifths rule. Given the Framers' understanding of judicial review, however, indeterminacy and subjectivity are substantial defects of a

79. TIEFER, supra note 77, at 257 \& n.16 Moreover, in 1982, the House Rules Committee prevented consideration of an important regulatory reform measure that had passed the Senate and had majority support in the House. Id. at 264.

80. The popularity of many of these items once they reached the floor was demonstrated by the very significant majorities they received, which included significant Democratic support. See Passage of Contract Bills, 53 CoNG. Q. 1006 (1995) (showing that bills incorporating Contract with America were supported on average by 333 members).

81. While the Open Letter describes the three-fifths rule as "unprecedented," it acknowledges that rules that it regards as constitutionally indistinguishable were enacted in 1985. See Open Letter, supra note 3, at $1539-43$.

82. The Open Letter itself provides no less than four different formulations for assessing which rules issued under the Rules of Proceedings Clause should be deemed constitutional: rules that allow the House to "organize itself for informed and efficient debate and decision," id. at 1541; rules aimed at "efficient decisionmaking," id.; rules of "general procedure aimed at inducing deliberative decisionmaking," id. at 1542; and rules not based on "substantive and selective judgments," id. at 1543. Some of the elements of these standards are themselves in substantial tension with one another. For example, rules that promote efficient decisionmaking tend to limit debate and frustrate attempts to encourage more fully informed discussion. 
constitutional rule to be applied by the judiciary. ${ }^{83}$ Such defects are even more serious than usual when assessing the constitutionality of rules that determine whether congressional legislation is law. Here formal and determinate rules like the one we suggest are particularly necessary; legislators (and citizens) must be able to know in advance whether their actions will be deemed legally binding in order to avoid the very substantial social costs that would result from uncertainty as to which bills become law. Jefferson's statement about parliamentary rules of procedure applies as well to the constitutional tests for assessing the constitutionality of these rules: "It is much more material that there should be a rule to go by than what that rule is ...." $\$ 4$ The Open Letter's vague standard for assessing the constitutionality of legislative rules would subject legislative proceedings to the "caprice" of judges and the "captiousness" of constitutional commentators. ${ }^{85}$

\section{REPEALING AND WAIVING SUPERMAJORITY REQUIREMENTS}

Although our argument has assumed that a majority of the House could eliminate the three-fifths rule, the Open Letter appears to argue that a twothirds vote would be needed. In this part, we argue that the Open Letter's reading of the House Rules is mistaken. We then argue, more fundamentally, that even if the House sought to prevent a majority from repealing a supermajority requirement, it could not constitutionally do so.

\section{A. The House Rules Permit a Majority to Waive or Repeal the Three-Fifths Rule}

The Open Letter mistakenly asserts that a standing rule of the House of Representatives may be modified only through suspension of the rules, which requires a two-thirds majority of those voting. ${ }^{86}$ In reality, a simple majority

83. It is a premise of judicial review that rules of constitutional decision be capable of fairly determinate and objective application. See THE FEDERALIST No. 78, at 469 (Alexander Hamilton) (Clinton Rossiter ed., 1961) (distinguishing judicial from political behavior because it represents "judgment" according to rules rather than mere exercise of political "will").

84. ThOMAS JefFerson, MANUAL OF PARLIAMENTARY PRACTICE, reprinted in H.R. DOC. No. 248, 100th Cong., 2d Sess. 117 (1975). Hatsell, the great English recorder of parliamentary rules and precedents, has expressed a similar sentiment: "[I]f the maxim 'Stare super vias antiquas,' has ever any weight it is in those matters where it is not so material, that the rule should be established on the foundation of sound reason and argument, as it is, that order, decency, and regularity, should be preserved in a large, a numerous and consequently often tumultuous assembly." 2 HATSEL, supra note 6, at 150 .

85. Cf. JEFFERSON, supra note 84 , at $117-18$ (stating clear legislative rules are required to avoid "the caprice of the Speaker or captiousness of the members").

86. Open Letter, supra note 3, at 1542. Although we interpret the Open Letter to deny that the threefifths rule can be temporarily waived or permanently repealed by a majority vote, we acknowledge some uncertainty on this point. The Open Letter may instead be asserting that the three-fifths rule can be temporarily waived only by a two-thirds vote, but can be permanently repealed by a majority. We hesitate 
may waive any standing rule of the House, including the three-fifths rule, by passing a measure called a "special rule." A simple majority of the House may also amend or repeal any standing rule of the House.

To understand the relation between suspension of the rules and passage of special rules, one needs only a basic understanding of the different mechanisms by which the House considers legislation. In the nineteenth century, the House of Representatives considered legislation through a mechanism that permitted each committee to call up the bills of its choice. This mechanism was not successful because it did not provide a means for prioritizing bills or limiting debate. ${ }^{87}$ After the reforms of Speaker Reed in the late-nineteenth century, the House developed two major routes to obtain floor votes on bills. ${ }^{88}$ The most important route is through the enactment of a special rule. In this procedure, the Rules Committee votes out a rule that will structure the procedures for considering a specific piece of legislation (hence the name special rule, which contrasts with the standing rules of the House of Representatives). ${ }^{89}$ The special rule must be passed by a simple majority of members voting. ${ }^{90}$ The House then considers the bill under the procedures established under the special rule. Those procedures may include the waiver of any standing rule of the House. ${ }^{91}$ In fact, the House has waived one or more standing rules numerous times in every session. ${ }^{92}$

Suspension of the rules is a different mechanism for passing a bill. Under this mechanism, a two-thirds majority of the members voting suspends all the rules and passes specific legislation..$^{93}$ Unlike the special-rule procedure,

to impute to the Open Letter the view that a majority of the House may repeal permanently the three-fifths rule, because it would be hard to reconcile this view with the Open Letter's claim that the three-fifths rule "erod[es] . . . our central constitutional commitments to majority rule and deliberative democracy." Id. at 1539. In any event, the ambiguity in the Open Letter's argument need not detain us too long because, under either interpretation, the Open Letter's position is mistaken.

87. See TIEFER, supra note 77 , at 253-54.

88. Id. at 252.

89. Id. at 269-74.

90. See 139 CONG. REC. H552-57 (daily ed. Feb. 4, 1993) (waiving House Rule XI(4)(b), which requires two-thirds majority to call up rule for consideration on same day it is presented to House); WALTER J. OleszeK, CoNGressional Procedures AND THE POLICY PROCESS 130 (3d ed. 1989) ("All rules must be approved by a majority of the House."); Stanley Bach, The Nature of Congressional Rules, 5 J.L. \& POL. 725, 745 (1989) ("House can adopt the [special] rule by simple majority vote.").

91. OlEsZEK, supra note 90, at 127 ("In recent Congresses, [the] Rules [Committee] has granted blanket waivers of all points of order against pending legislation."); TIEFER, supra note 77, at 285-91, 286 ("[W]aiver provisions may [say] . . . that all points of order are waived for the whole bill."); Bach, supra note 90, at 737 n.49 ("The only legislative rules the Rules Committee cannot propose to waive by special rule are clause 4 of Rule XVI, providing for the motion to recommit, and clause 7 of Rule XXIV, providing for Calendar Wednesday.").

92. For instance, the Budget Act requirements were waived 132 times in the 98 th Congress. See HOUSE COMM. ON RULES, SURVEY OF THE ACTIVITIES OF THE HOUSE COMMITTEE ON RULES, 98TH CONG., H.R. REP. No. 1192, 98th Cong., 2d Sess. 31 (1985).

93. See RuLES, supra note 1, House Rule XXVII. 
which requires two votes-one on the rule and one on the legislation itself-suspension of the rules requires only a single vote. ${ }^{94}$ The House generally uses this mechanism to pass relatively uncontroversial and minor legislation, although on occasion an important bill is passed under suspension. ${ }^{95}$ When a bill fails to get a two-thirds vote under suspension, the House has at times then passed it through use of a special rule, thus underscoring in fact that suspension of the rules and special rules are two distinct mechanisms for passing legislation. ${ }^{96}$

In addition to waiving its standing rules, the House may also amend or repeal them. The Rules Committee has continuing jurisdiction over the rules of the House and, pursuant to that jurisdiction, may recommend amendments to those rules. ${ }^{97}$ Such amendments may then be passed by a majority vote of a quorum of the House. ${ }^{98}$

The Open Letter's failure to understand the mechanisms for passing legislation in the House leads it into a major legal error. The three-fifths rule can be temporarily waived or permanently repealed at any time to raise income tax rates if a majority so determines. It is true that such changes would normally require the Rules Committee to recommend either waiving or repealing the three-fifths rule, ${ }^{99}$ but all proposed legislation similarly requires

94. TIEFER, supra note 77 , at 310 .

95. Id. at $296-300$.

96. Id. at 314.

97. See RULES, supra note 1 , House Rule $\mathrm{X}(1)(\mathrm{m})$.

98. The majority requirement for amending or repealing the rules is implicit in the House rules. The rules treat the requirement of a majority of those voting as a default position that applies in the absence of something expressly to the contrary in the rules. For example, the rules do not explicitly state that ordinary bills require a majority vote to pass. See id. House Rule XXI (bill passage); $c f$. id. House Rule $\mathrm{X}(1)(\mathrm{m})$ (giving Rules Committee jurisdiction over House rules); id. House Rule XI(4)(d) (requiring Rules Committee to issue reports of rule changes). Thus, the fact that the House rules do not specify a supermajority vote for an amendment to the rules indicates that a majority may do so.

The structure of the rules also indicates that they may be amended by majority vote. The House rules provide the Rules Committee with jurisdiction over the rules, see id. House Rule X(1)(m), as they provide other committees with jurisdiction over their substantive areas, see id. House Rule $X(1)(a)-(s)$. The rules also clearly provide the Rules Committee with authority to recommend amendments to, or repeals of, the rules. See id. House Rule XI(4)(d). Just as bills that other legislative committees recommend must be passed by the entire House, so must amendments and repeals of rules that are recommended by the Rules Committee. For examples of amendments to the House rules that passed by less than a two-thirds vote, see 135 CONG. REC. 8775 (1989) (59\% of House passing amendment to rules as part of Government Ethics Reform Act of 1989); 123 CONG. REC. 22,949 (1977) (57\% of House passing amendment to House rules).

99. It might be argued that, because the Rules Committee tends to be composed of a greater percentage of members of the majority party than are other committees, it will be more difficult to amend the three-fifths rule than other legislation, and this raises constitutional concerns. This argument, however, fails for two reasons. First, bills normally must be approved by the committee that has jurisdiction and the Rules Committee. Floor consideration of bills usually requires that the Rules Committee pass a special rule. Thus, amending the three-fifths rule is easier in this respect than passing a bill. Second, even if one focuses only on the Rules Committee, it is no less representative of the entire House than other House committees. The membership of the committee on Ways and Means, for example, also comes disproportionately from the majority party. More importantly, committees are typically unrepresentative of the entire House in other ways. For example, committees with jurisdiction over agriculture will tend to have members from farm 
committee recommendation. ${ }^{100}$ Rules changed are thus subject to the same procedures as any legislative proposal and may be blocked by a committee unless they are brought to the House floor in a discharge petition. ${ }^{101}$ Accordingly, the three-fifths rule can be changed as easily as can any existing rule or law. ${ }^{102}$

\section{B. The Constitution Prohibits the House from Requiring a Supermajority to Repeal a Rule}

Because the House rules permit a majority to repeal the three-fifths rule, we do not strictly need to address the issues that would arise if the House attempted to prevent a majority from repealing the three-fifths rule. These issues, however, are the most difficult and interesting ones raised by the Open Letter, so we believe it is appropriate to discuss them briefly. We believe that the best view is that, even if the House did attempt to prevent a majority from repealing the three-fifths rule, it could not constitutionally do so. Thus, a simple majority would still be able to repeal the three-fifths rule.

The issue may be addressed with a hypothetical. Suppose that, instead of passing a three-fifths rule that a majority could repeal, the House had passed the three-fifths rule and a special repeal rule that required a supermajority vote to repeal the three-fifths rule. This simple repeal rule would not prevent a majority from repealing the three-fifths rule. To repeal the three-fifths rule, a majority could simply pass resolutions that repealed the repeal rule and the

states, which may make it more difficult to pass or repeal certain types of bills. See supra notes $75-78$ and accompanying text.

100. Discharge petitions enable a majority of the members of the House to discharge measures from a committee so that they may be considered by the entire House. House Rule XXVI(4) permits such a majority to discharge special rules from the Rules Committee. See RULES, supra note 1, House Rule XXVI(4).

101. See supra note 100 .

102. Thus, the only way that one might argue that the Rules Committee's power to block a vote on proposed rules and legislation is unconstitutional would be to assert that the committee system was unconstitutional. The Open Letter, however, does not make that argument. In any event, the Open Letter argues that a majority could not discharge the three-fifths rule from the Rules Committee because a discharge petition requires a majority of the entire House rather than a mere quorum. Open Letter, supra note 3 , at 1542 . This argument is disputable. A discharge petition may be signed over an extended period of time. Thus, it is not clear what the relevant quorum is for the discharge petition. Indeed, there is a strong argument that the relevant quorum comprises ail members who were present in the House at any time during the entire period the discharge petition could have been signed. After all, a quorum is a measure of the number of members who could vote for a bill or rule, and, given a sufficiently long period, practically all members have the opportunity to sign the discharge petition. Under this analysis, the membership of the entire House would be nearly identical to the quorum for the discharge rule. The quorum for the discharge rule would diverge only to the extent there are members who are absent for extended periods, which should occur only rarely. Thus, a majority of the quorum would normally be able to discharge the three-fifths rule from the Rules Committee. 
three-fifths rule. ${ }^{103}$ In this way, a majority that chose to do so would have the power to circumvent the repeal rule.

To prevent this maneuver, the House might attempt to insulate the repeal rule from repeal by a majority. Thus, the House might pass a stronger repeal rule-call it the insulated repeal rule-providing that both it (the insulated repeal rule) and the three-fifths rule could only be repealed by a supermajority vote. We believe, however, that the Constitution does not allow such an insulated repeal rule to be given effect. In other words, as a constitutional matter the authority of a majority of the House to repeal a rule cannot be extirpated.

The view that a majority can repeal the insulated repeal rule is rooted in the history and structure of the Constitution. Before we explain our argument, it is important to emphasize that the constitutional issue raised here is not limited to the narrow question that we have asked about the insulated repeal rule. Rather, the constitutional issue is broader in two ways. First, although we are attempting to determine whether the House may require that a rule be repealed by a supermajority, it seems clear that, if the House had this power, it would also have the power simply to prevent repeal of a rule or, in fact, the passage of a rule. If the House had the power to require, for example, a twothirds vote to repeal a rule, there is no principled reason why it could not also require a $99 \%$ vote or entirely prohibit repeal of the rule. (With this power, the House could also pass a rule that would prevent it from passing particular kinds of rules in the future.) Second, although we are addressing the power of the House to insulate rules from repeal, the answer to this question would almost certainly apply to the analogous question raised with respect to legislation: Whether Congress can pass a law that will prevent it from repealing or passing a law in the future. ${ }^{104}$

Returning to the insulated repeal rule, our analysis begins with the constitutional text. Unfortunately, the text does not clearly resolve the issue. The Rules of Proceedings Clause merely provides that each house has the authority to pass the rules of its proceedings. It does not specify whether rules of proceedings may be insulated from repeal by a majority. Similarly, the Presentment Clause is silent on whether Congress may insulate a law from repeal by a future Congress.

103. See, e.g., 139 CONG. REC. H552-57 (daily ed. Feb. 4, 1993) (waiving by less than two-thirds majority House Rule XI(4)(b), which requires a two-thirds majority to call up for consideration a rule on same day it is presented to House).

104. For example, could Congress pass a law prohibiting future Congresses from increasing the existing speed limit on interstate highways? 
Although the text does not answer the question, the history and structure of the Constitution do. When the Framers drafted the Constitution, they did so against a traditional understanding of the limits of legislative power. The Framers were clearly aware of the traditional understanding, and absent evidence to the contrary, it must be assumed that they followed it. Blackstone states the traditional view in Book I of his Commentaries:

Acts of parliament derogatory from the power of subsequent parliaments bind not .... Because the legislature, being in truth the sovereign power, is always of equal, always of absolute authority: it acknowledges no superior upon earth, which the prior legislature must have been, if it's [sic] ordinances could bind the present parliament. ${ }^{105}$

Because each legislature is equal, one legislature cannot prevent a successor from taking action. ${ }^{106}$ Although Blackstone links this point about the equality of legislatures over time with the British notion of the sovereignty of Parliament, the equality of legislatures is a distinct point. While American law abandoned the principle of legislative sovereignty, it retained that of legislative equality. ${ }^{107}$

The structure of the Constitution also indicates that one legislature cannot bind another. If a legislature could pass a measure that would prevent a successor from taking action, then that measure would function as a constitutional restraint on the future legislature. For example, if the Senate passed a rule prohibiting tax increases, that would function exactly as if it were a constitutional prohibition on tax increases. As Thomas Cooley stated:

To say that the legislature may pass irrepealable laws, is to say that it may alter the very constitution from which it derives its authority;

105. 1 WILLLAM BLACKSTONE, COMMENTARIES *90. Blackstone traces the traditional view to Cicero. See 1 id.

106. Although The Federalist No. 78 addresses a different situation, Hamilton's article shows some recognition of this view. In discussing the case of two irreconcilably conflicting statutes, Hamilton writes that the courts must:

Of necessity ... give effect to one in exclusion to the other. The rule which has obtained in

the courts for determining their relative validity is that the last in order of time shall be preferred to the first.... [The courts] thought it reasonable that between the interfering acts of an equal authority that which was the last indication of its will should have the preference. THE FEDERALIST No. 78 , supra note 83 , at 468.

107. See Reichelderfer v. Quinn, 287 U.S. 315, 318 (1932) ("[T] he will of a particular Congress ... does not impose itself upon those to follow in succeeding years."); Manigault v. Springs, 199 U.S. 473, 487 (1905) (holding that general state statute enacted by legislature can be repealed or amended by enacting legislature); Newton v. Commissioners, 100 U.S. 548, 559 (1879) ("succeeding legislature possesses the same jurisdiction and power with respect to [public laws] as its predecessors"); THOMAS M. COOLEY, Constitutional Limitations 125-26 (Boston, Little, Brown, and Co. 1868); see also EARL T. CRAWFORD, THE CONSTRUCTION OF STATUTES 171, 193 (1940) (citing numerous state cases). 
since in so far as one legislature could bind a subsequent one by its enactments, it could in the same degree reduce the legislative power of its successors, and the process might be repeated until, one by one, the subjects of legislation would be excluded altogether from their control, and the constitutional provision, that the legislative power shall be vested in two houses, would be to a greater or less degree rendered ineffectual. ${ }^{108}$

Because the Constitution permits amendments only under the procedures in Article V, and not simply through legislative enactments, the legislature does not have the power to bind itself in the future. ${ }^{109}$

It is true that the text of the Constitution has been interpreted to permit legislatures to enter into binding contracts and to create vested rights in contract and property that a subsequent legislature cannot impair. ${ }^{110}$ But this authority specifically derives from the constitutional provisions protecting such rights, such as the Contracts Clause and the Takings Clause. ${ }^{111}$ The legislature, however, lacks the authority to prevent subsequent legislatures from changing the law when it passes ordinary statutes or rules of proceedings. ${ }^{112}$

108. CoOLEY, supra note 107 , at 125-26.

109. It might be argued that the traditional view that one legislature cannot bind a future legislature had a more limited meaning than we have given it. Under this alternative interpretation, the traditional view would prevent one Congress from binding a future Congress, but not from binding itself. Thus, the House of Representatives of the 103d Congress could not pass a rule that would bind the House of the 104th Congress, but it could bind itself during the 103d Congress. While this is a possible interpretation of the traditional view, we do not believe it is the better one. When Blackstone refers to a subsequent Parliament, we understand him simply to mean the Parliament at a later point in time. We are not aware of any evidence that British or American law has permitted one legislature to bind itself. More importantly, Blackstone's argument that each legislature is equal does not mean merely that the 103d Congress is the equal of the 104th Congress, but also that the 103d Congress on one day is the equal to the 103d Congress on a subsequent day. The structural argument that permitting one house to bind another would in effect permit a house to amend the Constitution also supports our interpretation. The Senate has traditionally been understood to be a continuous legislative body because two-thirds of the Senate of every new Congress has not stood for reelection. Julian Eule, Temporal Limits on the Legislative Mandate: Entrenchment and Retroactivity, 1987 AM. B. FouND. Res. J. 379, 408 (Senate has repeatedly endorsed view that it is a continuous body). Thus, under the traditional view of the Senate rules, if one legislature could bind itself, that would permit the Senate to bind itself permanently, which would effectively enable the Senate to amend the Constitution by passing unrepealable rules.

110. Even these protections have been weakened over time. See Stewart E. Sterk, The Continuity of Legislatures: Of Congress and the Contracts Clause, 88 CoLUM. L. REV. 647, 672-85 (1988).

111. See U.S. CONST. art. I, $\S 10$ (Contracts Clause); id. amend. V (Takings Clause).

112. The fact that a house needs only a majority vote to pass a rule adds support to the conclusion that a house cannot prevent a majority from repealing a rule. It would be odd to permit a house to pass, by majority vote, a rule that requires that its own repeal may only be achieved by a supermajority. This fact suggests something like an equal dignity rule: A rule cannot provide for its repeal by any greater proportion than that under which the rule was enacted. We do not believe the Constitution adopts the equal dignity rule. Rather, it simply forbids provisions that prevent a rule from being repealed by a majority vote. The executive branch, through the Office of Legal Counsel, has also held that one Congress cannot bind a subsequent one:

Clearly, Congress cannot by legislation prevent itself from enacting future legislation pursuant to whatever procedures it chooses to follow at that future time. A future Congress can always legislatively change what a previous Congress has done. In a legally enforceable sense, 
The view that the Constitution does not permit the House to require a supermajority to repeal a rule is also consistent with the Senate's long practice of requiring a supermajority to end debate on legislation. It might be thought that a simple majority of the Senate could not repeal the cloture rule, but that is mistaken. If the Senate voted on whether to change the cloture rule, only a simple majority would be needed to change it. ${ }^{113}$ It is true that an attempt to change the cloture rule might be filibustered, ${ }^{114}$ but that is another matter. The historical and structural argument presented above does not demonstrate that a majority must at all times be able to obtain a vote on all measures that it desires. ${ }^{115}$ Indeed, as discussed above, several longstanding legislative rules, including the rules governing the filibuster and the committee system, sometimes burden the ability of a majority to vote on bills and rules. ${ }^{116}$ Here we can state with some confidence only that when a house votes, the Constitution requires that a majority be able to repeal an existing rule. ${ }^{117}$

therefore, such future lawmaking would be regulated only by the requirements of the Constitution.

OLC Opinion, supra note 52, at 45.

113. As with the House, see supra note 98 , the Senate requirement that bills and rules be passed by a majority is implicit rather than explicit. The factors that indicate that a majority of the House may amend the rules apply with equal force to the Senate. The Senate Committee on Rules and Administration, like the House Rules Committee, has jurisdiction over the rules of its chambers, see SENATE MANUAL, supra note 32, Senate Rule XXV(1)(n), and its recommendations, like those of any Senate legislative committee when reported to the floor, are passed with a majority vote. Thus, the fact that there is no explicit supermajority requirement for amending the filibuster rule indicates that a majority may do so. See id. Senate Rule XXII (cloture rule). For an example of an amendment to the Senate rules that passed by less than a two-thirds or three-fifths vote, see 128 CONG. REC. 30,640-45 (1982) (approximately 59\% of Senators repealing Senate Rule XXXVD).

114. The current Senate rules make it more difficult in most instances to end the debate about a Senate rule than about a bill. See SENATE MANUAL, supra note 32, Senate Rule XXII (cloture requires three-fifths of Senators duly chosen and sworn except on measures to amend Senate rules, for which it requires twothirds of Senators present and voting). One effect of this rule is to make it harder for the Senate to amend the cloture rule.

115. Even if one argues that a majority must be able to obtain a vote on all questions, this does not render the three-fifths rule unconstitutional. Rather, it simply means that certain other rules of the house that prevent a majority from obtaining a vote would be unconstitutional. See infra note 117 .

116. As discussed above, until 1917 the Senate did not have any cloture rule, and since then cloture has always required a supermajority under the rules. See TIEFER, supra note 77, at 693-706; supra notes 64-65 and accompanying text; see also supra note 66 and accompanying text (House lacked effective mechanism to limit debate until end of nineteenth century). Similarly, the House did not have a rule permitting discharges of measures from committees until 1910, and the loopholes in that rule were eliminated only in 1931. See TiEFER, supra note 77, at 314-20. But see supra note 102 (arguing that present discharge rule might be interpreted as enabling a majority of quorum to obtain votes on measures). In addition, the scheduling of rules for floor consideration often required a two-thirds vote during most of the nineteenth century. See TIEFER, supra note 77, at 192-93, 254-55.

117. It is not clear what limitations, if any, the Constitution imposes on a chamber's power to prevent a majority from obtaining a vote on a measure. A brief discussion of two of the positions one might take on this issue should illustrate some of the problems. One position is that a majority must always be able to obtain a vote on all measures. Under this view, the committee system would be unconstitutional to the extent that it prevented a majority from voting on a measure. The committee system will not prevent the majority from voting on measures so long as a majority can waive or amend the rule preventing floor consideration of measures not reported by a committee. Thus, this position would prohibit the committee 


\section{The Three-Fifths RUle is GoOd Policy that AcCords With THE SPIRIT OF THE CONSTITUTION}

We believe that the three-fifths rule not only passes muster as a matter of positive constitutional law but also advances important policy goals, including the cause of democratic self-governance. The Open Letter unwisely seeks to cut off legitimate policy debates about how best to structure the legislative process in light of the current political landscape. By arguing that nonmajoritarian legislative rules are presumptively unconstitutional, for instance, the Open Letter attempts to dictate the proper balance between majority and minority legislative influence over legislation when the Constitution itself does not resolve this complicated issue of political science. ${ }^{118}$ In this respect, the Constitution is more flexible than the signers of the Open Letter believe.

In drafting the Constitution, the Framers' objective was to establish a wellfunctioning republic-a concept that is not necessarily synonymous with government by legislative majority. First, the Framers understood that legislative majorities were but an imperfect reflection of the majoritarian will of the people as a whole. ${ }^{119}$ Second, the Constitution was designed to protect individual rights as well as political rights. ${ }^{120}$ The Constitution's limitations on legislative and even popular majorities are apparent not only in the Bill of Rights but also in the entire structure of government. Bicameralism and the separation of powers make it difficult for mere majorities to pass legislation.

system from being used only to prevent votes on waivers or amendments to the rule barring floor consideration of measures not reported by a committee. For similar reasons, this position would prohibit the filibuster from being used only to prevent votes amending or waiving the rules governing the filibuster. One major problem for this position is that it would render part of the rules governing the committee system and the filibuster unconstitutional, even though such rules have venerable origins.

A second position is that each chamber should have broad discretion to establish rules that govem the scheduling of votes on measures. Under this view, each chamber's discretion must be broad enough to encompass at least the filibuster and the committee system. A problem for this view is that the chambers cannot have unlimited discretion to pass rules that regulate the opportunity to hold votes, because some versions of such rules function like extreme insulated repeal rules. For example, imagine that the Senate, after enacting the three-fifths rule, passed a second rule forbidding itself from ever taking a vote on whether to waive or amend the three-fifths rule or this second rule. While this rule appears unconstitutional, it may be a complex matter to fashion a principled distinction between it and the original filibuster (which was not subject to cloture).

118. In contrast, our requirement that legislative rules, rather than legislation, be subject to majoritarian legislative control is more modest. It does not resolve, by judicial fiat, complicated issues of political science such as the relative influence of different constituencies on legislators. Instead, it solves the inevitable coordination and recognition problems that face any legislative body. There must be a rule to determine how the legislature will fashion its own rules, and a majority rule is the most obvious focal point.

119. See, e.g., Akhil Reed Amar, The Bill of Rights as a Constitution, 100 YALE L.J. 1131, 1147-52 (1991) (suggesting that original purpose of First Amendment was to permit popular majorities to bring pressure to bear on potentially unrepresentative national legislative majorities).

120. See John O. McGinnis, The Partial Republican, 35 WM. \& MARY L. REv. 1751, 1760 (1994) (outlining manner in which Constitution is designed to protect individual rights). 
The original Constitution further restrained the power of a majority of the national legislature by dividing powers between the federal government and the states.

Thus, in passing the three-fifths rule, the Republican Congress not only acted in accord with the formal rule that can be derived from the text and structure of the Constitution but also with the overall architecture of the Constitution, because the rule will simultaneously protect the interests of popular, rather than legislative, majorities and protect the exercise of individual rights. One of the fundamental problems of democratic politics is that concentrated interest groups have more influence with legislators than diffuse groups, even if the diffuse groups represent a numerical majority. ${ }^{121}$ Public choice theory suggests, and observations confirm, that political entrepreneurs will therefore favor a legislative agenda that provides benefits to cohesive and organized interest groups while imposing costs on the electorate as a whole. ${ }^{122}$ Our present budget crisis is in large measure a reflection of repeated instances of this dynamic. Legislators will trade votes to provide entitlements and other expenditure programs to numerous concentrated interest groups. ${ }^{123}$ The taxes (or debt) required to pay for expenditures do not impose a substantial constraint on such activity because the incidence of the taxes (or debt) can be diffused over the entire population (and future generations, if possible) ${ }^{124}$ Thus, a three-fifths rule for taxes can be understood as a rough

121. Michael T. HaYes, LOBbyists aNd Legislators: A THEORY of Political Markets 91 (1981) (suggesting that concentrated costs and benefits are more likely to generate political and lobbying activity by organized groups); see Steven G. Calabresi, The Political Parties as Mediating Institutions, 61 U. CHI. L. REV. 1479, 1507 (1994) (arguing that a member of Congress "concerned with maximizing her potential to be reelected to Congress will want, ideally, to try to tax the nation as a whole, while steering a disproportionate share of the proceeds back to her district").

122. See E. Donald Elliott, Constitutional Conventions and the Deficit, 1985 DUKE L.J. 1077, 1090 (noting that government spending programs provide concentrated benefits while spreading costs of programs over large and diffuse groups).

123. The scenario is thus a specific example of the well-known paradox of vote trading. See William H. Riker \& Steven J. Brams, The Paradox of Vote Trading, 67 AM. POL. SCI. REv. 1235, 1236 (1973) ("This paradox [of vote trading] has the property that, while each trade is individually advantageous to the traders, the sum of the trades is disadvantageous to everybody, including the traders themselves.").

124. Our argument assumes that restrictions on tax rates function, especially in the long run, to limit spending. While it might be argued that any reduced taxes will merely be replaced with increased debt, this is not true. There are checks on Congress's ability to run large deficits; otherwise, Congress would lower taxes and run much larger deficits. Both taxes and debt are generally opposed by voters, but to different degrees and by different groups. Public choice theory suggests that, if Congress is not otherwise constrained, it will finance spending with the combination of taxes and debt that minimizes the opposition to the program that it passes. Any rule, such as the three-fifths rule, that forces Congress to alter this combination should thereby increase the opposition to Congress's financing and spending program and therefore lead to less spending. In other words, if the three-fifths rule forces Congress to finance spending with large deficits that would be even more unpopular than higher taxes, this will induce Congress to spend less than it otherwise would have.

This theoretical argument is confirmed by political observation. Large deficits are now cited, particularly by the new Republican majority, as the primary reason to cut spending. See Kenneth J. Cooper, House Panel Softens Defense Measure, WASH. POST, Feb. 1, 1995, at A1 (noting that Republicans had to 
attempt to restore a more, rather than less, democratic balance between those adversely affected by taxes and those advantaged by expenditures. ${ }^{125}$ Moreover, because taxes encroach on individual rights, the rule also directly attempts to facilitate the protection of liberties.

The rule thus functions as a modest precommitment by the majority not to go down a road that will make everyone worse off in the end as concentrated interest groups demand expenditures that beggar the nation as a whole. ${ }^{126}$ While the Open Letter views the three-fifths rule as an imprudent incursion on our constitutional tradition, ${ }^{127}$ the House can easily change the rule in response to popular opposition. In fact, the Gramm-Rudman Act, which represented another kind of precommitment by the legislative branches to

reduce their own planned defense expenditures because of pressure to reduce deficit). Indeed, supporters and critics of the Reagan tax cuts of the early 1980s have, respectively, celebrated and deplored the curtailment of government expenditures that the resulting deficits appeared to cause. See Daniel P. Moynihan, Sick of Stockman and LaRouche, NEw REPUBLIC, May 26, 1986, at 16 (observing that both Friedrich Hayek, who approved of the strategy, and Moynihan, who did not, believed that deficits were "deliberately created to force a great reduction in the size and activities of the federal government").

Although the three-fifths rule should therefore pressure Congress to reduce spending, we recognize that spending might be reduced more effectively if the rule applied not merely to increases in income tax rates, but also to increases in taxes generally and to the public debt. Indeed, a more direct way to limit spending would be to apply the three-fifths rule to spending increases. Unfortunately, these versions of the rule may not have been politically feasible.

125. It might be argued that the three-fifths rule would actually give special interests greater power because they need only two-fifths of either house to block legislation. Cf. supra notes $34-43$ and accompanying text (discussing Madison's statement that Convention rejected constitutional supermajority rules because they might confer undue power on certain groups). The effects of supermajority rules on special interests will depend on the circumstances. While supermajority rules in some areas could give special interests even greater power, this is not true of the three-fifths rule for income tax increases. It has been our argument, which public choice theory supports, that special interests have generally exercised their power to secure benefits that have required increases in government spending and taxes. Because the threefifths rule makes it more difficult for special interests to increase spending and taxes, it impedes the power of special interests.

126. The Constitution is itself a societal precommitment to limit the range of future choices, and this is justified by the idea that choices prohibited by the Constitution will generally be socially disadvantageous. See Donald J. Boudreaux \& A.C. Pritchard, Rewriting the Constitution: An Economic Analysis of the Constitutional Amendment Process, 62 FoRdHAM L. REV. 111, 123 (1993). The precommitment of the three-fifths rule is much less dramatic than a constitutional precommitment because it can be changed by a majoritarian legislative process rather than a constitutional amendment. Nevertheless, the codification of the precommitment in a legislative rule generates political pressures that militate against its abandonment. Party officials and the public can monitor a member's voting behavior with respect to a clear rule of the House prominently adopted as a formal party position more easily than they can monitor voting behavior with respect to quotidian legislation. Put bluntly, because of the clarity and prominence of the rule, a Republican member of Congress would pay a much higher political price in waiving it than in voting for a tax increase, particularly when such increases can come disguised in many forms-for instance, as "revenue enhancers."

Even when supported by political considerations other than party discipline, rule-based precommitments in other areas have been kept and are believed to have had beneficial social effects. See, e.g., Harold Hongju Koh, The Fast Track and United States Trade Policy, 18 BROOK. J. INT'L L. 143, 163-66 (1992) (discussing manner in which precommitment represented by fast track procedures in international trade has facilitated negotiation of trade treaties).

127. See Open Letter, supra note 3, at 1539. 
eliminate the budget deficit, was changed by a legislative majority. ${ }^{128}$ If anything, one might argue that the three-fifths rule is too easily changed. While a constitutional amendment, such as the proposed balanced budget amendment that would require a sixty-percent majority to pass tax increases, would be less easily avoided, the three-fifths rule may be defended as a prudent experiment in addressing the problem of interest-group power. Thus, the three-fifths rule is appropriately viewed not as the reckless endeavor that the Open Letter portrays, but rather as a cautious exercise of statesmanship.

The Open Letter also complains that this precommitment was established on the first day of the congressional session without the benefit of further deliberation. But the public choice analysis outlined above suggests that there are public benefits of a party running on a platform, such as the Contract with America, containing such a rule and implementing it while the public's attention remains focused on its promises. This is one way of restraining the natural process by which concentrated interest groups gain undue leverage with legislators.

\section{CONCLUSION}

The three-fifths rule is entirely constitutional. The best textual reading of the Constitution demonstrates that Congress, acting by majority vote under its explicit rulemaking authority, may require supermajorities for votes on specific legislation. The rule is also in keeping with our constitutional history, because the history of legislative procedure, whether of the filibuster or of the committee system, is a history of tempering the power of legislative majorities in order to promote values other than majoritarian rule. The values advanced by this rule-deliberation among the legislators, diminution of the influence of rent-seeking interest groups, and protection of individual rights-are not simply legitimate constitutional values. They are values central to the original Constitution.

128. Gramm-Rudman set budget deficit targets for the fiscal years 1986 to 1991 and required acrossthe-board spending cuts if the budget targets were not met. See Balanced Budget and Emergency Deficit Control Act of 1985, Pub. L. No. 99-177, 99 Stat. 1037 (1985). If implemented, it would have eliminated the budget deficit by 1991 , but it was largely repealed in the budget deal between President Bush and Congress in 1990. See Stanley E. Collender, THE Guide to tHe Federal Budget 19-22 (1993) (discussing substantial revisions of Gramm-Rudman). 
